\title{
Synkrone online læringsmiljøer \\ - didaktisk design for synkron \\ undervisning understøttet af \\ digitale teknologier
}

\section{Ove Christensen}

Lektor

Forskning og Innovation, University College Sjælland

\section{Karsten Gynther}

Lektor og Forskningsprogramleder

Leder af Educationlab, University College Sjælland

\section{Rasmus Leth}

\section{Vergmann Jørn $\varnothing$}

Adjukt

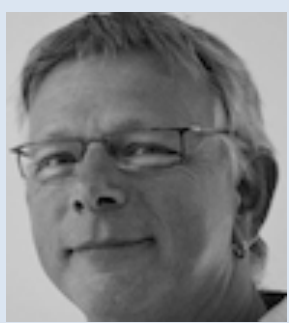

Forskning og Innovation, University College Sjælland
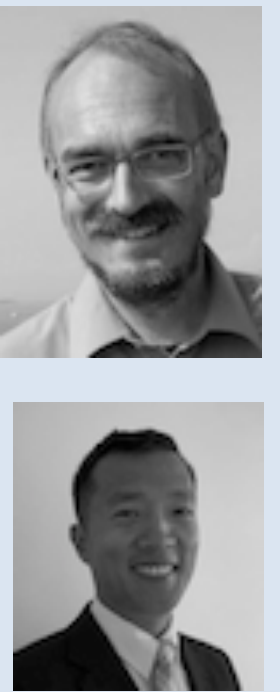
Ove Christensen har tidligere undervist på Aalborg Universitet ved Institut for Kommunikation. Nu ansat som forsker i UCSJ, hvor han arbejder med udvikling af uddannelsesdesign og didaktisk design understøttet af digitale teknologier.

Karsten Gynther er leder Education lab - UCSJs forskningsprogram for teknologi og uddannelsesdesign. Programmet arbejder med eksperimentelle og anvendelsesorienterede forskningsprojekter relateret til udvikling af didaktisk design understøttet af nye teknologier og er bl.a. inspireret af Design Based Research.

Rasmus Leth Vergmann Jørnø er ansat som forsker i forsker i UCSJ, hvor han arbejder med udvikling af uddannelsesdesign og didaktisk design understøttet af digitale teknologier med særlig fokus på materialiteters betydning i innovative processer. 


\section{Abstract}

Synkrone online læringsmiljøer muliggør realisering af en didaktisk praksis, der synkront kobler forskellige kontekster. Forskning i og udvikling af didaktiske principper, som kan guide uddannelsesudviklere og undervisere i deres arbejde med at udvikle didaktiske designs for synkrone læringsmiljøer, er imidlertid kun i sin spæde vorden. I denne artikel introduceres til et overordnet designframework for synkrone onlinelæringsmiljøer samt en række konkrete didaktiske principper, som eksemplificeres med en række designeksempler. Det overordnede framework rummer tre dimensioner i et didaktisk design for synkrone læringsmiljøer, der i kort form kan præsenteres som: a) simulering af tilstedeværelsesundervisning, b) remediering af tilstedeværelsesundervisning og c) innovativ transformation af tilstedeværelsesundervisning.

\section{English abstract}

Synchronous online learning environments allow the realization of a didactic practice that creates contextual couplings. Research and development of didactic principles to guide teachers and developers of education in developing designs for synchronous learning environments is however still in its infancy. This article introduces a series of new conceptual tools and didactical principles for online learning environment and includes a general design framework for synchronous online learning environments and concrete didactic principles exemplified through a set of design examples. The framework outlines three dimensions of a didactic design: a) simulation of face-to-face teaching, b) remediation of face-to-face teaching and c) innovative transformation of face-to-face teaching.

\section{Introduktion}

I vores forskning har vi været optaget af transformativ forskning (Ravn, 2010), og vi arbejder med didaktiske designproblemer. Vores forskningsprojekter er pragmatiske, dvs. vi forsøger at innovere didaktisk praksis, og da vi med innovation forstår en ide omsat til en ny og bedre daglig praksis (dvs. noget som organisatorisk kan forankres) er målet med vores forskningsprojekter at udvikle uddannelsesdesigns og didaktiske designs, som også kan anerkendes inden for givne institutionelle præmisser, og som ikke kræver udvikling af en helt nyt pædagogisk eller fagdidaktisk grundsyn hos de deltagende undervisere og uddannelsesinstitutioner, der deltager i vores forskningsprojekter. Selvom vores udgangspunkt er pragmatisk, så vil de udviklede didaktiske designs alligevel ofte betyde, at der opstår innovative transformationer af gængse undervisningsformer. Men dette handler i højere grad om, at udvikling og integration af "irriterende" teknologier ofte sætter en professionel didaktisk refleksionsproces i gang hos de deltagende undervisere. Det komplekse samspil mellem teknologiers potentialer, begrænsninger, http://www.lom.dk 
brugernes kompetencer og valg af uddannelsesdesigns og didaktiske designs åbner nemlig ofte op for paradoksale situationer, hvor f.eks. en digital teknologi muliggør innovation af et uddannelsesdesign (f.eks. udbud af et nyt fleksibelt uddannelsesformat i tid og rum) samtidig med at teknologiske begrænsninger ved samme digitale teknologi i første omgang forringer de didaktiske designs (f.eks. en mindre dialogisk orienteret undervisning), men at netop denne form for begrænsning eller ramme kan fremtvinge didaktisk innovation, som ikke blot udvikler de designs, der anvendes i institutionens nye uddannelsesdesigns, men som også virker innovativt tilbage på didaktiske designs i institutionens traditionelle uddannelsesdesign.

I denne artikel inddrages empiri fra et forskningsprojekt, hvor vi har medvirket til udvikling af et nyt uddannelsesdesign til adgangskursus til diplomingeniøruddannelserne på DTU/Campus Ballerup, som muliggør deltagelse for studerende, der i dag ikke har mulighed for at tage en ingeniøruddannelse. Det didaktiske designproblem, som projektet arbejder med, kan formuleres på følgende måde:

Hvordan designer man en uddannelse i tid og rum, der på en gang er så fleksibel, at man som studerende kan arbejde ved siden af studiet, og som samtidig er legitim for uddannelsesinstitutionen DTU/Ballerup ved, at den også indløser undervisere og studerendes krav til en tydelig undervisertilstedeværelse med mulighed for studiestilladsering og løbende og umiddelbar faglig feedback indlejret i en social ramme, hvor det at deltage $i$ en uddannelse også opleves som det at deltage i et studiefællesskab?

Baggrunden for formuleringen af dette designproblem er et forstudie, hvor vi identificerede en helt ny målgruppe til diplomingeniøruddannelserne på DTU/Campus Ballerup (Frederiksen mfl. 2013) Denne målgruppe har brug for en fleksibel undervisningstilrettelæggelse, der umiddelbart er i konflikt med DTU/Campus Ballerups pædagogiske profil, som lægger vægt på fremmødeundervisning og en tæt relation mellem underviser og studerende.

\section{Forskningsdesign}

Projektets forskningsdesign er inspireret af Design Based Research en forskningstilgang initieret af bl.a. Ann Brown (1992) og Allan Collins (1992). Denne forskningstilgang har vi introduceret til i (Christensen, Gynther og Petersen 2012). Design-Based Research (også kaldet Educational Design Research) er forskning, der genererer ny viden gennem processer, som samtidig udvikler, afprøver og forbedrer et didaktisk design. Som forsker făr man derved en vanskelig dobbeltrolle, idet man som DBRforsker både er "forsker" og "designer". Som forsker er man interesseret i at udvikle ny forståelse i form af teori, men samtidig er man også dybt involveret $i$ at designe en ny praksis eller et artefakt, som kan indgå i 
udviklingen af et nyt didaktisk design. Denne udfordring diskuteres grundigt i artiklen "Balancing Product Design and Theoretical Insights" (Ejersbo mfl. 2008), hvori forfatterne udvikler en model, der beskriver to parallelle processer, som guider henholdsvis forskerrollen og designerrollen (Se figur 1).

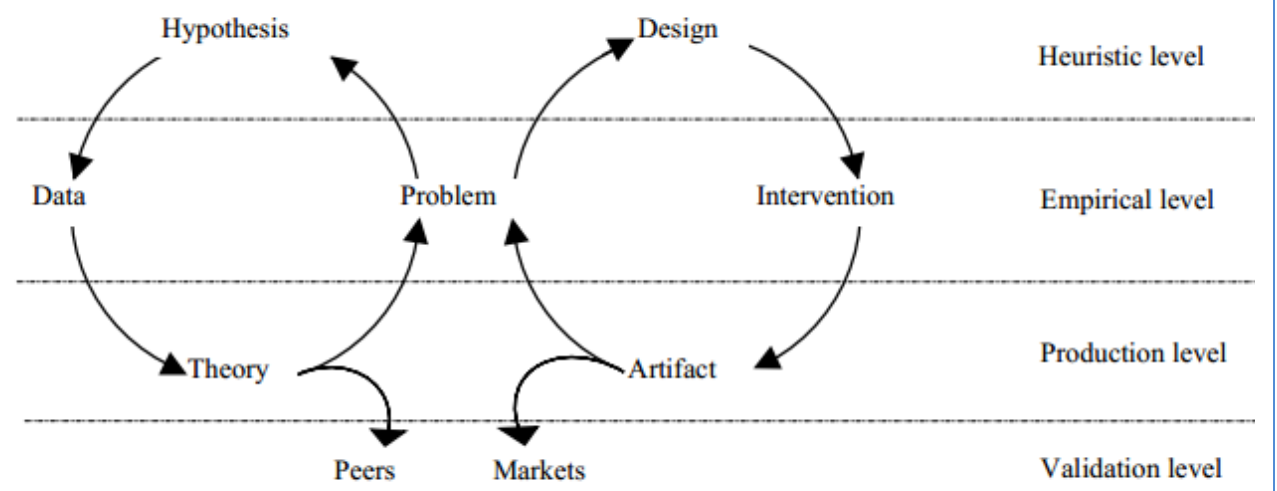

Figur 1. En model for dobbeltrollen som designer og forsker i DBR projekter

Udgangspunktet for begge roller er (jf. modellens midte) en problemstilling fra en (uddannelses)praksis. Designerrollen arbejder her iterativt i faserne: problem, design, intervention og endeligt artefakt (hvis kvalitet vurderes af markedet/brugerne), mens forskerrollen arbejder parallelt med faserne: problem, hypotese, data og teoriudvikling (hvor sidstnævntes kvalitet kan vurderes af fagfæller).

Den højre side af modellen illustrerer design-eksperimenter, som (hvad modellen ikke viser) består af iterative forløb, der i en given uddannelsespraksis tester og forbedrer de første prototyper, der er udviklet i den indledende ide- og designfase. Målet er at udvikle designs, som er så robuste, at de kan anvendes i forskellige kontekster (diSessa \& Cobb, 2004). Det er vigtigt at understrege, at forskningsprocessen også er iterativ, hvilket betyder, at man ikke kun evaluerer en intervention, men systematisk forsøger at forbedre designet, mens man samtidig producerer designprincipper, der kan guide lignende forskning (Amiel \& Reeves, 2008).

Udvikling af designet vil forløbe som en serie af forløb i form af test og forbedringer og en løbende indsamling af data med henblik på at kunne redefinere problemer, mulige løsninger og de principper, som ligger bag en foreslået løsning. Analyser af og refleksion over data anvendes til at skabe nye designs, som efterfølgende igen afprøves, evalueres, analyseres og redesignes. Selve evalueringen i denne proces handler om at forbedre; ikke at http://www.lom.dk 
bevise kvaliteten af en prototype. Evalueringen handler om at undersøge om designet er gennemførligt i en hverdagspraksis, om det er relevant for deltagerne at bruge, om designet bevarer sin legitimitet i forhold til deltagernes krav til designet, og om det er effektivt i forhold til tid, økonomi, oplæringstærskel mv. (Mckenney et al., 2006).

Gennem et designeksperiment etableres mulighed for teoriudvikling med udgangspunkt i praksis, hvilket også kendes fra forskningstilgangen "Grounded Theory" (Glaser og Strauss, 1967).

Den teorigenerering, som et designeksperiment kan generere, er designframework i form af en række didaktiske designprincipper, der kan formidles gennem en eller flere designeksempler (Hrastinski mfl. 2010). I den prisbelønnede artikel af Hrastinski m.fl. 2010 udfoldes ovenstående tre centrale begreber. Da denne tænkning ikke er så kendt i dansk sammenhæng, vil vi kort eksemplificere, hvad vi forstår ved "designframework", "didaktiske designprincipper" samt "designeksempler". Disse tre begreber er centrale for at forstå det konkrete designeksperiment på DTU/Campus Ballerup, som beskrives nedenfor.

Et i dansk sammenhæng velkendt eksempel på et didaktisk designframework er "Projektarbejdsformen" (Illeris, 1981). Projektarbejdsformen er defineret ved tre didaktiske designprincipper: problemorientering, deltagerstyring og eksemplarisk læring (op. cit). Disse tre designprincipper kan som al anden didaktisk teori ikke være foreskrivende for praksis. Didaktik som videnskabelig disciplin trækker på human- og samfundsvidenskabelige forskningstraditioner, og didaktiske designprincipper er refleksionskategorier, som praktikere og uddannelsesudviklere kan anvende til at reflektere over, udvikle og planlægge egen didaktisk praksis. Didaktiske designprincippers mulighedsrum for konkret didaktisk praksis kan formidles gennem didaktiske designeksempler, hvilket ikke skal forstås som "eksempler på best practice", men som cases, der kan facilitere og inspirere praktikere m.fl. til at udvikle egne didaktiske design for præcis den uddannelseskontekst, som vedkommende befinder sig i. I dansk sammenhæng har Undervisningsministeriet udgivet en række bøger, der eksemplificerer brugen af projektarbejdet i danske uddannelser, og med begreber fra DBR er disse udgivelser at betragte som designeksempler på projektarbejdet.

Ovenstående eksempel kan også bidrage til at løse et andet formidlingsproblem, vi har iagttaget i vores arbejde med at udvikle nye didaktiske designs. Anvendelsen af designbegrebet inden for didaktikken er nemlig også forholdsvis nyt i Danmark (Andresen, 2008). Vi har især iagttaget at forskere og udviklere, der kommer fra en teknologi- eller ITsystemudvikler-tradition forstår designbegrebet som håndgribelige 
artefakter, vi som mennesker kan gøre noget med. For folk med denne ekspertbaggrund er begrebet "didaktisk design" svært at forstå - for hvor er det håndgribelige, hvor er artefaktet, hvor er det, som er udviklet i et givent projekt? Her er projektarbejdsformen et godt eksempel, der kan tydeliggøre, hvad det er, vi arbejder med. Et konkret projektarbejde i en konkret uddannelsesinstitution er et didaktisk design. Dette kan iagttages både gennem de ideer, skitser og planer, der er for den konkrete afvikling Det er også muligt at iagttage de artefakter i bred forstand, som inddrages i undervisningen (teknologier mv.), og det er muligt at observere realiseringen af det didaktiske design i tid og rum ved at være observatør i en konkret undervisningssituation. Det er denne forståelse af et didaktisk design, vi har arbejdet med i vores udvikling af et designframework og didaktiske principper for synkrone læringsmiljøer.

Det udviklede designframework og de beskrevne designeksempler for synkrone online læringsmiljøer, som præsenteres nedenfor, er derfor ikke og kan ikke være foreskrivende for praksis Men i kraft af det domænekendskab samt den eksisterende forskning, der ligger bag udviklingen af frameworket, samt en række empiriske afprøvninger er det didaktiske designframework, som præsenteres, valide planlægnings- og refleksionsværktøjer, som uddannelsesplanlæggere og undervisere må omsætte i konkrete uddannelsesdesigns og didaktiske designs, som også medtænker den kontekst, de som praktikere står i.

\section{Projektmetode}

Da DBR er en bred forskningstilgang, findes der mange forskellige fasemodeller og mere konkrete metodiske principper, man konkret kan anvende. I dette projekt har vi anvendt Thomas Reeves firfasede forskningsmodel med følgende faser (Reeves, 2006, Amiel \& Reeves, 2008):

Fase 1: Problemidentifikation (foretaget af forskere og praksisdeltagere i fællesskab, som analyser af problemer i en given praksis)

Fase 2: Udvikling af løsningsforslag (med udgangspunkt i eksisterende designprincipper og teknologiske innovationer)

Fase 3: Iterative forløb (af test i praksis og forbedring af designs)

Fase 4: Refleksion (med henblik på at producere "designprincipper" og forstærke implementeringsmulighederne)

Fase 1 er afrapporteret i (Frederiksen mfl. 2013) og ligger til grund for formulering af det ovenfor skitserede designproblem, som projektet konkret forsøger at løse.

Fase 2 blev indledt med et litteratur-review (se nedenfor) med fokus på synkrone e-læringsformer, idet analysen i fase 1 entydigt pegede mod 
denne type uddannelsesdesign. Derefter blev der afholdt en række codesignworkshop mellem forskere fra "Forskningsinstitution Y" og DTU/Ballerups undervisere på adgangskursus (AK). Med inspiration fra allerede kendte designprincipper fra forskning i synkrone e-læringsformer og med teknisk introduktion og støtte til brug af værktøjet Adobe Connect (AC) blev der til AK udviklet en række didaktiske prototyper for synkron undervisning i fagene engelsk, matematik, dansk, fysik/kemi og samfundsfag. Der blev i alt afholdt 8 co-designworkshop inden de første prototyper kunne testes i praksis. Med prototyper forstår vi både undervisernes didaktiske design herunder deres plan for undervisningens afvikling samt den mere konkrete indretning af det netbaserede læringsmiljø i AC, som skulle understøtte den konkrete afvikling af undervisningen.

I fase $3 \mathrm{blev}$ fire prototyper (didaktiske designs) afprøvet blandt DTU/Ballerups nuværende studerende på adgangskursus. De didaktiske designs bestod af et undervisningsforløb i hver af de fire deltagende fag på en enkelt lektion. Afprøvningerne af de planlagte sessioner er blevet fulgt af forskerne gennem deltagelse i selve online undervisningen, og da alle undervisningssessioner er blevet optaget i AC (en integreret funktionalitet i Adobe Connect), har vi efterfølgende analyseret alle fire testsessioner, som hver varede ca. 1 time. Selve analysen af datamaterialet fra observationerne og fra de optagede sessioner er inspireret af Grounded Theory, idet vi har set det samme datamateriale igennem, og på fælles forskningsværksteder har vi i udviklet og mættet de kategorier, som vil blive præsenteret nedenfor. Analyser og begreber er efterfølgende blevet præsenteret og diskuteret på fælles udviklingsværksteder mellem forskere og undervisere med særlig fokus på validering af kategorierne og re-design af de udviklede prototyper.

Fase 4 handler om generaliseringsmulighederne i et designeksperiment. Spørgsmålet er i hvor høj grad et udviklet designframework kan applikeres på andre kontekster end præcis den, som designeksperimentet er udført i. Her følger vi den udbredte metode i DBR at arbejde med skalering (Mckenney et al., 2006), hvor et designs robusthed valideres gennem afprøvninger med nye deltagere, der ikke får samme støtte, som dem, der har bidraget til udviklingen af et givent design. I forhold til skalering kan man skelne mellem tre forskellige typer af afprøvninger (Mckenney et al., 2006): alfa-, beta- og gammaafprøvning.

Alfa-afprøvning: Konteksten er ideel og forsøgt kontrolleret af forskerne.

Denne type afprøvning har vi anvendt i en form, hvor underviserne fra DTU/Ballerup simulerede studerende i et AC miljø, idet vi introducerede en række af designprincipperne for brug af synkrone onlinemiljøer gennem en synkron online session med underviserne. Her blev en række af de 
principper, som kunne udtrækkes af litteraturreviewet, introduceret for underviserne i de fire fag gennem en konkret synkron onlinesession, hvor vi som forskere havde rollen som undervisere og underviserne agerede studerende. På baggrund af denne alfa-afprøvning udformede underviserne det, man kan kalde en visuel prototype, dvs. et didaktisk design formuleret som en skitse/en plan for en konkret undervisningssession i deres fag. På fælles designworkshop fik underviserne sparring fra os forskere på deres visuelle prototyper (planer), hvorefter lærerne i en redesignfase reviderede deres didaktiske design samtidig med, at de byggede en funktionel prototype for selve undervisningsmiljøet i AC. Igen på en fælles designworkshop blev de funktionelle prototyper fremlagt med henblik på at videndele om potentialer og begrænsninger i programmet AC. Derefter byggede underviserne en færdig prototype af onlineundervisningsmiljøet, som kunne afprøves for studerende i en beta-afprøvning.

Beta-afprøvning: Konteksten er nøje udvalgt og tilbydes support.

Denne type test blev afviklet i foråret 2013 for alle fire fagområder og fulgt af forskerne både gennem direkte synkron deltagelse i real time, ligesom vi efterfølgende analyserede sessionerne, som alle blev optaget på video i AC.

Gamma-afprøvning: Her er fokus på spredning i stor skala med minimal support.

Pt. er planlagt at udbyde et fleksibelt adgangskursus fra januar 2014, som kombinerer synkron, asynkron og tilstedeværelsesundervisning $\mathrm{i}$ weekends - et blended learning forløb med udbredt brug af princippet om the flipped classroom (Strayer, 2007, Tucker, 2012). Denne afprøvning vil fortsat blive fulgt af forskerne, som vil opsamle erfaringerne med denne form for afprøvning,

\section{Litteraturreview}

En række litteraturreviews de senere år viser, at forskning i synkrone læringsmiljøer har været sparsom (Asterhan mfl. 2010, Teng mfl. 2012, Hrastinski mfl. 2010, Robertsen mfl. 2012). Der er derfor mangel på didaktisk teori og didaktiske principper, som undervisere kan anvende ved design af synkron onlineundervisning (Robertsen mfl. 2012). Ja, indtil for få år siden har didaktiske principper været helt fraværende (Hrastinski mfl. 2010). Størstedelen af forskningen i online-miljøer har haft fokus på asynkrone miljøer, og den forskning i synkrone læringsmiljøer, der dog findes, viser, at der er meget stor forskel på de to forskellige former for læringsmiljøer. Størstedelen af forskningen i asynkrone læringsmiljøer når frem til, at styrken ved disse miljøer er, at der er tid til refleksion og diskussion af komplekse emner (Asterhan mfl., Hrastinski mfl 2010, Robertsen mfl 2012). Men der er også megen forskning, der viser, at der 
kan opstå problemer med isolation i et asynkront læringsmiljø (Hrastinski mfl 2010, Rich mfl. 2009, McBrien mfl. 2009).

Et andet stort problem ved asynkrone læringsmiljøer kan være manglen på umiddelbar, øjeblikkelig, just in time feedback til studerende i forhold til deres læreproces (Li mfl. 2011). Den helt store fordel ved synkrone læringsmiljøer er da også muligheden for real time feedback og evaluering af de studerendes arbejde (Asterhan mfl.2010, Hastie mfl. 2007, Karal mfl 2011). Studerendes vurdering af kvaliteten af et online læringsmiljø er tæt koblet til deres mulighed for at få feedback på deres arbejde (Asterhan mfl. 2010), og der er da også en høj korrelation mellem omgående verbal og nonverbal respons og så studerendes læringsudbytte (Hastie mfl. 2007).

Synkrone læringsmiljøer muliggør interpersonal kommunikation (Rich mfl. 2009), som indtil da kun har været muligt i tilstedeværelsesundervisning. Studerende oplever heller ikke i et synkront læringsmiljø den samme følelse af isolation, som ofte er forekommende i asynkrone læringsmiljøer. De kan opleve en "klasserumsfølelse" når onlinemiljøet muliggør real-time interaktion mellem studerende og undervisere (Rich mfl. 2009, Hwang mfl. 2012, McBrien mfl. 2009, Karal mfl. 2011, Teng mfl. 2012). Synkrone teknologier muliggør social interaktion, men om disse muligheder indløses afhænger af det didaktiske design (McBrien mfl. 2009). Som allerede nogle af de tidligste fjernundervisningsteorier gjorde opmærksom på (Moore, 1993), så separerer onlineundervisning underviser og studerende, men denne distance er psykologisk og kommunikativ ikke geografisk betinget (More 1993, McBrien mfl 2009). Oplevelsen af at være til stede i et onlinemiljø (presence) er subjektiv og opstår gennem og understøttes af interaktion med et miljø, hvor interaktionen overbeviser brugeren om, at han/hun er til stede i onlinemiljøet (Teng mfl. 2012). Presence forstået som individuel oplevelse er den enkeltes oplevelse af, at en medieret afbildning af virkeligheden erfares på samme måde som en ikke medieret virkelighed. (Lee, 2004).

Man kan derfor skelne mellem physical presence, social presence og self presence, hvilket er den enkeltes oplevelse af, at medierede fysiske genstande opleves som virkelige, at sociale aktører i onlinemiljø opleves som virkelige aktører, og at man oplever sig selv som tilstedeværende i onlinemiljøet (Lee, 2004). Forskning i hvordan man kan understøtte presence er central for udviklingen af didaktiske principper for design af synkrone online læringsmiljøer. Der findes her især to tilgange, som kan føres tilbage til diskussionen af begrebet "telepresence", der blev lanceret af Mavin Minsky i 1980 (Minsky, 1980).

En teknisk tilgang til begrebet telepresence har fokus på alt det, som kan øge eller mindske "båndbredden" mellem deltagerne i et onlinemiljø. Her fokuseres bl.a. på, at non verbale kommunikationsmuligheder med 
billede/video, håndsoprækningsfunktioner mv. er vigtig for oplevelsen af nærvær, ligesom tekniske problemer med lyd mv. øger oplevelsen af distance (McBrien mfl. 2009). Men det at kunne se og høre hinanden giver ikke i sig selv en oplevelse af at være til stede eller opleve, at man er en del af et læringsmiljø (Teng mfl. 2012).

En social orienteret tilgang til telepresencebegrebet har derimod fokus på, hvad deltagerne anvender medier/teknologierne til, samt hvordan de understøtter deltagernes indbyrdes relationer. Her har fem faktorer særlig betydning for deltagernes oplevelse af social presence i et online miljø: social respekt (f.eks. ved at få respons), deling af informationer og holdninger, åbenhed, identitet (f.eks. ved at blive kaldt ved eget navn) og intimitet (f.eks. ved at dele personlige erfaringer) (Sung og Mayer, 2012). Tillid mellem deltagerne i et onlinemiljø bliver derfor helt central for opbygningen af social presence med henblik på at understøtte uddannelsesrelevante interaktioner mellem de studerende indbyrdes og mellem de studerende og underviseren (Teng, 2012). Sung og Mayers fem faktorer er generelle for onlinemiljøer, men der har også været forsket i, hvordan social presence kan understøttes i et formaliseret online læringsmiljø.

Moores teori om "transactional distance" peger bl.a. på, at graden af distance skabes af tre elementer: dialogen, strukturen og den lærendes muligheder for autonomi (Moore, 1993). Og det var Moores hypotese, at en løs didaktisk struktur kombineret med en høj læringsautonomi samt gode dialogmuligheder mindsker oplevelsen af distance. Dette har andre forskere ikke kunnet eftervise empirisk, og Moores teori opfattes da også som en tautologi - når forståelse øges så mindskes misforståelser (Gorsky mfl. 2005). Dette forhindrer dog ikke, at Moores teori har inspireret senere forskning til at fokusere på det didaktiske design, og hvordan dette understøtter oplevelsen af social presence for den studerende (McBrien, 2009).

En ofte citeret teori, som også er blevet kritiseret fra flere sider, er teorien om Community of Inquiry (COI) (Garrison, 2011, Garrison og Vaughan, 2008). Garrisons hypotese er, at den studerendes "educational experience" afhænger af tre presence-former: social presence, teaching presence og cognitive presence dvs. den studerendes oplevelse af at deltage i et socialt fællesskab, af det didaktiske design samt af den studerendes læreproces. For Garrison er det tre ligeværdige faktorer, som han dog erkender ikke har været muligt at identificere empirisk (Garrison, 2011).

Et litteraturreview over forskning, som har taget udgangspunkt i COIteorien (Annand, 2011) viser, at der er meget som tyder på, at det er det didaktiske design (teacher presence), som er den primære faktor i et formaliseret online læringsmiljø. Det didaktiske design 
(undervisertilstedeværelse) er en vigtig faktor for de studerendes oplevelse af social presence, og det er det didaktiske design/lærertilstedeværelsen, som sammen med det sociale miljø tilsammen faciliterer de studerendes læreprocesser (Asterhan, 2010). Med henblik på at understøtte presenceoplevelse i et online læringsmiljø er det vigtigste derfor at have fokus på det didaktiske design. Det centrale her er design af interaktioner mellem a) underviser og de studerende, b) de studerende indbyrdes og c) den studerende og det faglige stof/indhold (Teng mfl. 2012).

I et synkront onlinelæringsmiljø kan relationen mellem studerende og underviser og de studerende og andre studerende trække på kendte elementer fra tilstedeværelsesundervisningen og her primært den interpersonelle kommunikationsform og mulighederne for feedback fra underviser. Denne lighed med tilstedeværelsesundervisningen har fået mange undervisere til at forsøge at overføre et didaktisk design fra deres tilstedeværelsesundervisning direkte til onlinemiljøet. Det er her muligt at organisere sekvenser af forskellige typer af interaktioner i kulturelt genkendelige situationer f.eks. klasserummets IRE model (Initiation, Respons, Evaluering) (Sullivan mfl. 2010)

Men generelt kan man ikke blot overføre et didaktisk design fra tilstedeværelsesundervisningen til et online miljø uden væsentligt kvalitetstab (Nehme mfl. 2008, Asterhan mfl. 2010, Rich mfl. 2009) Stort set alle didaktiske elementer skal redesignes til brug i onlinemiljøet (Robertsen mfl. 2012). I denne redesignproces har det inden for elæringsforskningen været almindeligt at koble redesign med læringsteoretiske præferencer (Dirckinck-Holmfeld, 2004, Dohn og Johnsen, 2009) eller formulere innovationshierakier, skalaer eller trin, som implicit eller eksplicit beskriver en pædagogisk praksis, der går fra dårlig til god - f.eks. når man beskriver redesignprocesser som enten "erstatning", "forstærkning" eller "transformation" af tilstedeværelsesundervisningen (Robertsen mfl. 2012). Den normativitet, der ligger i disse kategoriseringer har vi tidligere kritiseret (Gynther 2005).

Inden for e-læringsforskning findes der da også en anden tilgang til analyse af redesignprocesser af tilstedeværelsesundervisning, som tager udgangspunkt i en pædagogisk tænkning, der kombinerer forskellige typer af videns- og færdighedsformer med forskellige pædagogiske praksisformer (Qvortrup, 2001) - praksisformer som ikke kategoriseres i forhold til en kvalitetsskala, men som hver især er legitime pædagogiske praksisformer.

Til brug for den redesignproces, der er nødvendig, når man går fra tilstedeværelsesundervisning til undervisning i et onlinemiljø, kan man i dag anvende en række forskellige teknologier, hvoraf nogle samler 
forskellige funktioner i et og samme værktøj, hvilket får nogle forskere til at kalde disse værktøjer for "et fuldt integreret synkront online læringssystem" (Nehme mfl. 2008, Robertsen, 2012). Et eksempel på et sådan system er $\mathrm{AC}$, hvis funktionaliteter vi beskriver nedenfor, og som kan anvendes til at designe det, vi kalder et "synkront online læringsmiljø". Et læringssystem som AC muliggør en række forskellige didaktiske designs. Om disse muligheder så også kommer i spil afhænger ikke kun af teknologiens muligheder og begrænsninger i sig selv), men også af underviseres og de studerendes kompetencer og valg i forhold til brug af teknologien (Robertsen mfl. 2012) samt af en række andre rammefaktorer, som sætter teknologien ind i en konkret social (uddannelsesinstitutionel) ramme.

Sammenfattende peger litteraturreviewet på et overordnet designframework i form af et synkront online læringsmiljø, som i den efterfølgende konkrete udviklingsproces endte med at blive et blended learning-miljø med hovedvægt på synkrone kommunikationsformer, der kombineres med månedlige fysiske fremmøder samt brug af asynkrone kommunikationsformer og en udbredt anvendelse af princippet om "the flipped classroom" (Strayer 2007, Tucker 2012).

\section{Forskningsresultater: Designframework - didaktiske principper og designeksempler for synkrone online læringsmiljøer}

Som det er fremgået ovenfor, så er projektet pt. ikke afsluttet, men en første analyse af vores datamateriale har genereret tre helt overordnede design-dimensioner, der vil kunne anvendes af forskere og didaktikere til både at analysere og reflektere over egen og andres undervisning i og med synkrone læringsmiljøer, ligesom de kan anvendes som designframework for didaktisk designarbejde i konkrete kontekster.

De tre overordnede kategorier er:

- Simulering af tilstedeværelsesundervisning

- Remediering af tilstedeværelsesundervisning

- Innovativ transformation af tilstedeværelsesundervisning

Inden vi præsenterer de tre kategorier, er det vigtigt at gøre opmærksom på, at de tre kategorier ikke skal forstås som en taksonomi eller skala for dårlig/god praksis for design af online læringsmiljøer. Simulering, remediering og innovativ transformation er alle gyldige og komplementære principper for design af synkrone onlinemiljøer. 


\section{Simulering af tilstedeværelsesundervisning}

Vores analyse af de afviklede synkrone onlinesessioner viser, at det i et synkront online miljø er muligt at simulere eller mime det, som foregår i tilstedeværelsesundervisningen. Når man simulerer eller mimer tilstedeværelsesundervisning handler det om at udvikle et didaktisk design, der indeholder en række kontekstmarkører, som den studerende kan anvende til at skabe genkendelighed i forhold til en kulturel situation og dermed aktivere deltagernes vanlige repertoire af deltagelsesformer i den kulturelle situation, som de nu genkender.

I det følgende udfoldes princippet om simulering af tilstedeværelsesundervisning gennem de muligheder, som vi har kunnet iagttage, at underviserne i projektet har anvendt med brug af værktøjet AC.

Den centrale kontekstmarkør for tilstedeværelsesundervisning er synkron kommunikation i real time. Dette kan man enten understøtte ved, at ACmiljøet giver deltagerne mulighed for at kommunikere synkront med åbne mikrofoner, men man kan også etablere andre synkrone kommunikationsformer f.eks. gennem en chatfunktion, som er en del af onlinemiljøet. Vi observerede, at kombinationen af mundtlige og skriftlige synkrone kommunikationsformer blev anvendt i alle de afviklede sessioner.

"Krop og bevægelse" er også et kendetegn ved tilstedeværelsesundervisningen, hvilket vi kunne se også kan simuleres i større eller mindre grad. Med et webcam kan man se ansigtsudtryk, selvom dette dog afhænger af billedkvalitet herunder lysforhold i det rum, hvor deltagerne befinder sig. Man kan også anvende et tilkoblet mobilt webcam til at vise andre typer af bevægelser i et rum, f.eks. ved at kameraet optager personer eller kropsdele som bevæger sig. Sidstnævnte mulighed blev bl.a. anvendt af en af underviserne jf. billedet nedenfor, hvor underviseren filmer sig selv gå til tavlen for at lave en gennemgang af en opgave. 


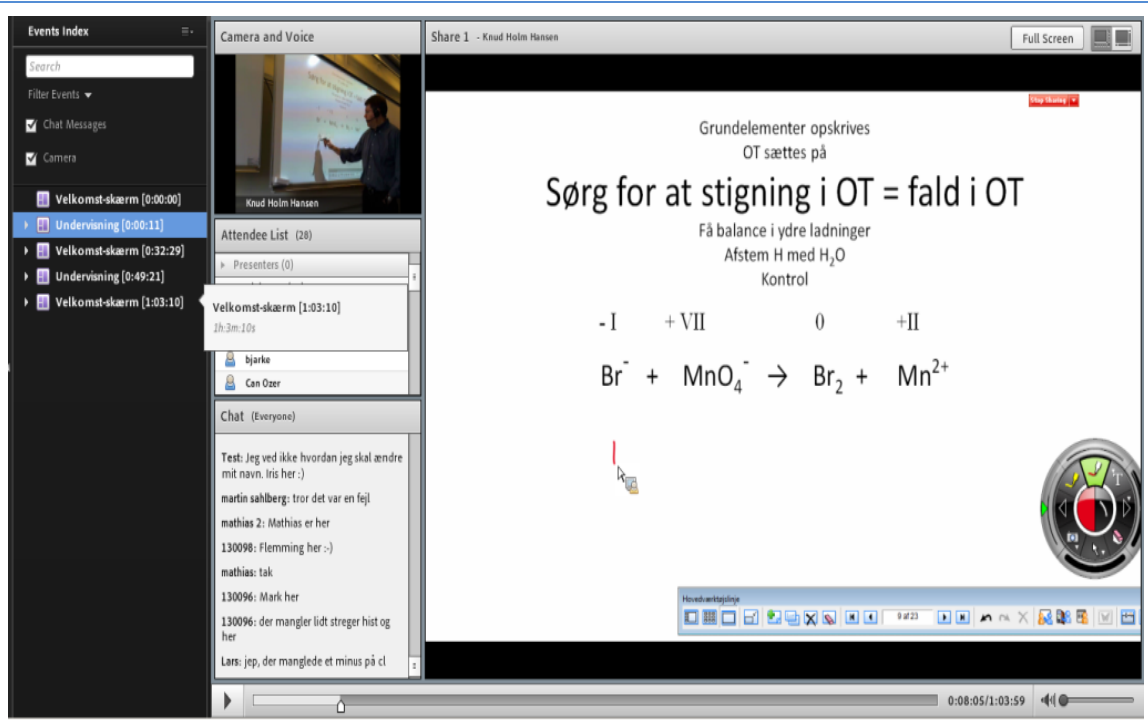

Figur 2. At mime kroppen i rummet

I mindre grad kan man mime bevægelser og kropssprog med en tilknyttet håndsoprækningsfunktion, hvor deltagernes online-figur (avatar) kan rejse hånden eller benytte sig af andre typer af feedbacktilkendegivelser. Det afgørende ved alle disse muligheder i den synkrone kommunikation er, at man med disse kommunikationsmuligheder kan mime den form for umiddelbar feedback, som kendes fra tilstedeværelsesundervisningen.

Men som vi var inde på i litteraturreviewet, så handler deltagernes oplevelse af tilstedeværelse kun i mindre omfang af, om et onlinemiljø mimer kommunikationsmedier og kommunikationsmuligheder fra tilstedeværelsesundervisningen. Som nogle af de første fjernundervisningsteorier gør opmærksom på (Moore, 1993), så handler oplevelsen af tilstedeværelse ikke om teknologier (eller medier), men om hvad vi som mennesker gør med disse medier. Det handler om sociale processer, så det vigtigste designprincip for simulering af tilstedeværelsesundervisning er overvejelser vedr., hvordan man mimer de sociale processer, der foregår i tilstedeværelsesundervisningen.

Som vi var inde på tidligere, så er det centrale spørgsmål her, hvordan man etablerer en oplevelse af at være til stede i en undervisningssituation. Tre forskellige tilstedeværelsesformer kan understøtte studerendes oplevelse af at være til stede i en undervisningssituation (Garison and Norman, 2008):

- Lærertilstedeværelse: Oplevelsen af en tydelig tilstedeværelse af underviseren som netop underviser

- Social tilstedeværelse: Oplevelsen af at man er den af en fælles gruppe og i videre forstand et fællesskab, som deler vilkår og interesser 
- Personlig tilstedeværelse: Oplevelsen af at man som studerende har mulighed for at interagere med undervisningens indhold (stoffet), med underviseren og med sine medstuderende

Nyere forskning i presence relateret til undervisning (Annand, 2011) viser, at alle tre dimensioner er vigtige for de studerendes læring, men lærertilstedeværelse er den vigtigste faktor, når det gælder de studerendes oplevelse af tilstedeværelse i en undervisningssituation. Som også nogle af grundlæggerne af teorien om de tre tilstedeværelsesformer i undervisningen erkender (Garison og Vaughan, 2008), så er de tre former ikke isolerede kommunikations- eller adfærdsformer, der kan adskilles og iagttages empirisk. I tilstedeværelsesundervisningen er de tre tilstedeværelsesformer ofte til stede samtidig i de typer af sociale processer, som karakteriserer undervisning. Med henblik på didaktiske simuleringsovervejelser vælger vi derfor at trække på Moores teori om Transactional distance, idet Moore her introducerer nogle begreber, som kan anvendes i analysen af undervisningen som social proces.

Vi er enige i kritikken af Mores teori om "Transactional distance" - især hans tese om, at jo mere ustruktureret det didaktiske design er, og jo mere læringsautonomi, designet lægger op til, jo mindre oplever den studerende at være distanceret fra underviser og medstuderende. Men hans to grundbegreber "dialogue" og "structure" har inspireret os til at analysere vores datamateriale ud fra, hvilken struktur de sociale processer i tilstedeværelsesundervisningen har, samt hvilke kommunikationsformer der kendetegner de enkelte elementer i undervisningens struktur med henblik på efterfølgende at simulere disse i det synkrone onlinemiljø. Vi har her sammenlignet vores observationsnoter fra første fase af projektet, hvor vi over to dage observerede de deltagende underviseres tilstedeværelsesundervisning, og efterfølgende har vi så sammenlignet med vores videooptagelser af de synkrone onlinesessioner i AC.

Helt overordnet viser denne analyse, at det var forholdsvist nemt for underviserne at mime de strukturer, som tilstedeværelsesundervisningen er organiseret efter, ligesom det også var muligt at mime de fleste af de kommunikationsformer, der blev anvendt i

tilstedeværelsesundervisningen, med en meget betydningsfuld undtagelse, som vi skal vende tilbage til nedenfor.

Med struktur forstår vi rækken af sekvenser i en undervisning, hvor en sekvens er en afgrænset tidsmæssig periode, som har et bestemt formål, og hvor der er specifikke roller for underviser og studerende med henblik på at realisere formålet med sekvensen. På AK er tilstedeværelsesundervisningen den mest udbredte sekvens et fagligt oplæg fra en underviser. I sin rene form er denne sekvens meget klar i sin 
kommunikationsform. Underviser "tegner og fortæller", og de studerende lytter. Vi har iagttaget, at denne type sekvens næsten i "en til en" form kan mimes i et online miljø.

En række værktøjer til produktion af onlinemiljøer er da også produceret med det formål at understøtte en envejskommunikationsform, hvilket man især ser i webinarformen, hvor en ekspert formidler et indhold, mens flere hundrede deltagere synkront kan se og lytte med til formidlingen. Denne sekvenstype er i sin helt rene form ikke særlig almindelig i dansk pædagogisk tradition, som i højere grad vægter kommunikationsformen "dialogisk holdundervisning". Vi kunne både i vores alfatest samt i de efterfølgende betatestsessioner se, at den dialogiske kommunikationsform har vanskelige vilkår i et synkront onlinemiljø som AC. Det er især lydproblemer (herunder støj og lydforsinkelse) samt færre redundante kommunikationsmuligheder (kropssprog mv.), som gør det umuligt at arbejde med kommunikationsformer med hurtig turtagning, med flere der taler i munden på hinanden, med folk der afbryder mv. Konsekvensen af dette for det didaktiske design vender vi tilbage til under kategorien "Remediering af tilstedeværelsesundervisning".

Andre velkendte sekvenser fra tilstedeværelsesundervisningen på AK, som analysen også viste, at det er muligt at mime i et fuldt udviklet værktøj til design af onlinelæringsmiljøer, er f.eks. "fremlæggelser", "forståelseskontrol", "test" "gruppearbejde" og "vejledning". Sekvensen "fremlæggelse" indeholder f.eks. præcis de samme kommunikationsformer som ved underviserens fremlæggelser. Her er det blot i sin rene form en studerende, der "tegner og fortæller", mens underviser og resten af de studerende lytter. Vi kunne iagttage, at underviserne med et værktøj som AC ikke havde problemer med at facilitere dette, idet underviseren i ACmiljøet kunne give de studerende de samme rettigheder, som underviser havde (til præsentation, skærmdeling mv.). Nedenstående er et eksempel på dette fra en af de optagede sessioner. Det er her en studerende (nederst til højre), der fremlægger en opgavebesvarelse på det fælles whiteboard. 


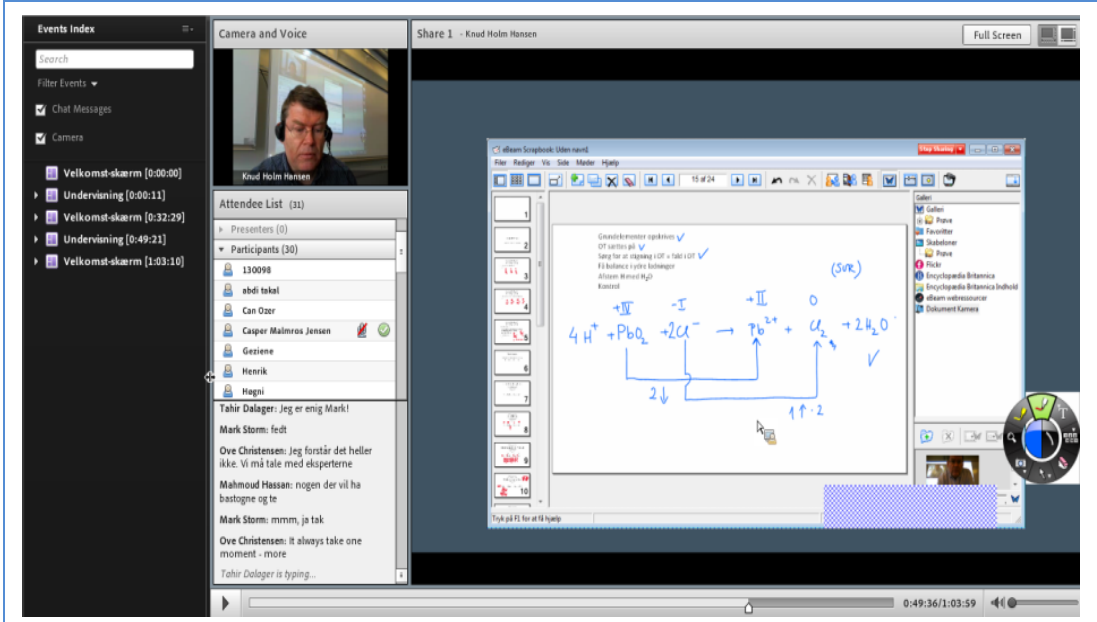

Figur 3.At mime sekvensen "forståelseskontrol"

En anden velkendt sekvens fra tilstedeværelsesundervisningen på DTU/Ballerup er "forståelseskontrol", hvormed vi mener, at underviser stiller et spørgsmål og de studerende tilkendegiver, at de vil svare, hvorefter underviser tildeler dem svarrettigheden. Sekvensen og de dertil tilknyttede kommunikationsformer blev af underviserne også mimet i online-miljøet f.eks. når underviserne stillede mundtlige spørgsmål gennem sin mikrofon, og de studerende med håndsoprækningsfunktionen tilkendegav, at de ville svare, hvorefter underviseren (eller den studerende selv) åbnede for den studerendes mikrofon (som havde været slukket for at undgå mikrofonstøj), og den studerende svarede. Indsamling af svar fra flere studerende samtidig og egentlige test var der også en af underviserne, der simulerede i onlinemiljøet, idet han her anvendte det værktøj til fremstilling af test (Polls), som også er integreret i AC-miljøet. Den meget udbredte sekvens "gruppearbejde" med dens dynamiske og dialogorienterede kommunikationsformer med tilhørende kollaborationsværktøjer simulerede underviserne også i onlinesessionerne. Det synkrone online miljø blev her indrettet med grupperum, hvor de studerende i mindre grupper kunne se og tale med hinanden over webcam (og vi kunne iagttage, at der ikke var lydproblemer når antallet i gruppen ikke var for stort), ligesom de studerende i grupperum arbejdede med spørgsmål og ressourcer, som underviserne i forvejen havde placeret i grupperummet som en del af indretningen af deres funktionelle prototype for AC-miljøet.

Opsummerende kan vi sige, at vi kunne iagttage, at man gennem simulering af tilstedeværelsesundervisningen i særlig grad har mulighed for at understøtte lærertilstedeværelse, men analysen af de optagede sessioner viste også, at den studerendes mulighed for at deltage aktivt i undervisningen og få umiddelbar feedback på sine præstationer eller spørgsmål er mulige at mime i et synkront online læringsmiljø. På et punkt 
kunne vi se, at man ikke kan simulere tilstedeværelsesundervisning, og det er den spontane dialog med flere kommunikationsdeltagere. Lydproblemer ved teknologien umuliggør dette og er en begrænsning ved teknologien AC, som vi kunne se fik store konsekvenser for det didaktiske design, hvilket vi vender tilbage til i det næste afsnit.

\section{Remediering af tilstedevarelsesundervisning}

Som vist i litteraturreviewet så peger forskning i onlinemiljøer på, at det ikke er muligt at oversætte tilstedeværelsesundervisning i en 1 til 1 form til onlineundervisning. Det grundlæggende design fra

tilstedeværelsesundervisning kan - som vi var inde på ovenfor - fastholdes i en form, som simulerer kontekstmarkører, der signaler tilstedeværelsesundervisning, men det er nødvendigt at remediere stort set alle enkeltelementerne i det didaktiske design.

Når vi vælger at bruge begrebet remediering om den transformationsproces, der sker, er det fordi vi definerer både tilstedeværelsesundervisningen og online-læringsmiljøet som et særligt kommunikationsmedie, der som mål har at bidrage til, at studerende tilegner sig bestemte færdigheder, viden og kompetencer. Remedieringen inddrager alle faser og alle elementer i en undervisningssekvens og kan derfor også kategoriseres som en re-didaktisering, hvor alle didaktiske elementer i det didaktiske design må redesignes.

Remedieringen starter med undervisningens begyndelse. I alle former for undervisningssituationer starter man som underviser med at konstatere om undervisning er mulig, dvs. om kommunikationspartnerne er til stede, og om kommunikation mellem deltagerne er mulig (Luhmann, 2000). I tilstedeværelsesundervisningen foregår dette typisk ved, at underviseren åbner døren til undervisningslokalet og konstaterer, om de studerende er til stede. I et synkront onlinemiljø skal denne type handlinger remedieres i form af processer, der ligner, men alligevel er helt anderledes. I alle de optagede sessioner kunne vi da også se, at undervisningen startede med, at underviseren tjekkede, om de studerende var logget på, og der blev foretaget lyd- og billedkontrol for at se, om lyden og webcam fungerede tilfredsstillende.

En vigtig remedieringsproces handlede om, hvordan underviseren forholdte sig til konsekvensen af de store lydproblemer, der ofte er i synkrone online miljøer til sammenligning med tilstedeværelsesundervisningen. Som vi var inde på ovenfor, så var det ikke muligt at afvikle en dialogorienteret holdundervisning i AC. Den tekniske understøttelse af telepresence var mangelfuld, idet der ofte var lydproblemer, ligesom webkamerabilleder ofte havde en ringe kvalitet, hvilket tilsammen øgede oplevelsen af at være distanceret fra de andre deltagere. Konsekvensen er, at dialogisk fleksibel kommunikation med 
hurtig turtagning og mange som bidrager i en stor holddiskussion var umulig/svær. Og denne teknologiske begrænsning ved AC betød, at kommunikationsformen blev mere envejs, når der var mange tilstede, idet det kun var muligt at lade én tale ad gangen, mens alle andre havde deres mikrofoner slukket.

De endimensionelle kommunikationsvilkår og oplevelsen af fjernundervisning stiller krav om et didaktisk design, som understøtter social telepresence. Det var derfor nødvendigt i samarbejde med underviserne at udvikle et didaktisk design, som maksimalt understøttede de studerendes oplevelse af, at de deltog aktivt i undervisningen Dette udviklingsarbejde foregik i de co-designworkshops, som er beskrevet ovenfor.

Her viste projektet, at et lovende svar på en indretning af det didaktiske design, som fastholder interaktionsmulighederne, samtidig med at kommunikationsvilkårene er endimensionelle, er en nedbrydning af undervisningen i korte sekvenser. Hver sekvens opstilles med forskellige formål, roller og aktiviteter i form af oplæg, små øvelser, forståelseskontrol, oplæg, større øvelser, test, opsummering eller vejledning mv. F.eks. viste projektet, at der var gode erfaringer med en model med sekvenser på mellem 5 - 15 min afhængig af sekvensens indhold.

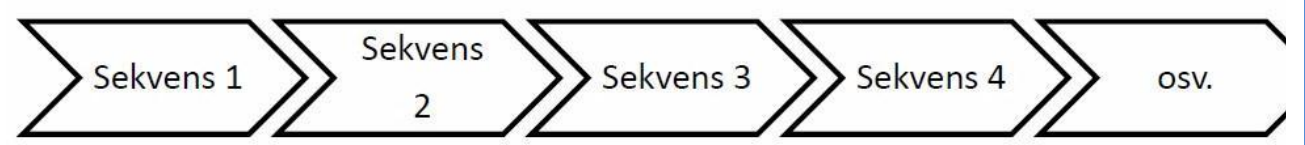

Figur 4. Sekvensopdelt undervisning

Udøver de korte sekvenser så viste projektet også, at det øger oplevelsen af interaktion samtidig med at oplevelsen af undervisertilstedeværelse fastholdes, hvis der veksles mellem sekvenser, hvor det er henholdsvis underviser og studerende, som kommunikerer (endimensionelt) på denne måde.

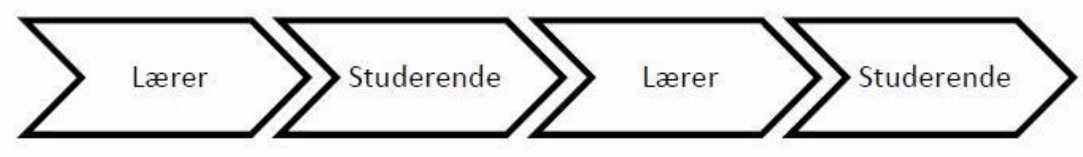

Figur 5. Veksling mellem lærer og studenteriniteret envejs kommunikation

Vi kunne imidlertid se, at denne sekvensopbygning ikke var nok til at overkomme de udfordringer, som primært lydmæssige udfordringer skabte i onlinemiljøet. I projektet opstillede vi derfor i samarbejde med 
underviserne en række principper for design af undervisningen med fokus på interaktion:

- Den enkelte studerende skal bidrage/være aktive i hver eneste onlinesession

- Det didaktiske design skal understøtte samarbejde mellem de studerende i form af gruppeaktiviteter

- Det didaktiske design skal understøtte en studiepraksis, hvor de studerendes deltagelse (evt. kollaboration) fastholdes i et medium (artefakt), som kan tilgås under og efter undervisningen - og som er et udtryk for og skabt i en fælles studieproces med medstuderende

\section{Didaktisk design som understøtter interaktion}

Underviserne udviklede herefter didaktiske designs med udgangspunkt i disse principper og indrettede deres onlinemiljø på en måde, så det kunne understøtte realiseringen af et didaktisk design med fokus på interaktion. Vores efterfølgende analyse af de optagede sessioner viste, at det med et værktøj som AC er muligt at remediere dialogorienterede og kollaborationsorienterede praksisformer kendt fra tilstedeværelsesundervisningen med udgangspunkt i ovenstående principper. Vi kunne her se, at realiseringen både handlede om det didaktiske design - om undervisernes kompetencer i at bruge værktøjet AC - og vi kunne se, at det også handlede om, at teknologien AC indeholdt en række medier og værktøjer, som alle var en forudsætning for undervisernes realisering af et didaktisk design med fokus på dialogisk og kollaborativ undervisning.

Vi foretog derfor en nærmere analyse, hvor vi sammenlignede de medier og værktøjer, der var til stede i tilstedeværelsesundervisningen med de medier og værktøjer, som var tilgængelige i onlinemiljøet AC. Analysen viste, at fuldt integrerede værktøjer til design af online læringsmiljøer som $\mathrm{AC}$ indeholder fem forskellige undervisningsmedier, som er integreret i et og samme værktøj:

1) Repræsentationsmedier

2) Dialogmedier

3) Præsentationsmedier

4) Kollaborationsmedier

5) Organiseringsmedier

Vi definerer de fem medier på følgende måde: 
Ved repræsentationsmedier forstår vi alle former for repræsentation af deltagertilstedeværelse i onlinemiljøet. Det er både kamerabillede (still eller video) af deltagerne, det er realtime kommunikation med lyd, det er de ikonografiske figurer suppleret med login-navne, som viser, at man er logget på, og det er en chatbesked, der langsomt vokser frem på skærmen relateret til et afsendernavn.

Ved dialogmedier forstår vi medier, som understøtter interpersonal kommunikation i real time f.eks. webcam med lyd samt chatfunktionen.

Ved præsentationsmedier forstår vi alle de former, hvor deltagerne kan vise præsentationer for hinanden, og som i AC-værktøjet kan være multimodale udtryksformer.

Ved kollaborationsmedier forstår vi alle de værktøjer, som kan fastholde og samle input fra forskellige deltagere i et fælles medie, og som kan gøre det synkront som eksempelvis et fælles whiteboard eller et fælles noteværktøj, som begge er integrerede funktioner i AC.

Ved organiseringsmedier forstår vi værktøjer, som kan organisere antallet af deltagere og som kan veksle mellem forskellige organiseringsformer. Her muliggør AC, at man med et enkelt klik kan veksle mellem en organisering, hvor alle er til stede, og en organisering i mindre grupper (break-outs). Et centralt potentiale ved AC er også, at værtøjets repræsentationsmedier, dialogmedier, præsentationsmedier og kollaborationsmedier er potentielt til stede i alle typer af organiseringsformer dvs. også i de grupperum/gruppeinddelinger, som man kan vælge at sætte de studerende ind $i$.

De fem former for medier er velkendte, men det, som dette projekt i særlig grad har vist, er betydningen af, at alle fem medier et nemt tilgængelige for underviseren i et og samme værktøj. Vi kunne se, at integrationen af alle fem funktioner i samme værktøj inviterer til, at man som underviser også anvender mulighederne. Når underviserne fik introduceret værktøjer og didaktiske muligheder i AC, så blev de med det samme integreret i undervisernes didaktiske design, og det endda selvom vi kunne se, at ACværktøjet var vanskeligt tilgængeligt og krævede en del øvelse at anvende.

\section{Innovation transformation af tilstedeværelsesundervisningen}

Den sidste dimension vi vil trække frem fra vores analyse af datamaterialet, vil vi beskrive som innovative transformationer af tilstedeværelsesundervisningen. Vi kan iagttage, at overgangen til et synkront onlinemiljø ikke kun handler om at kompensere for teknologiske begrænsninger enten ved at simulere oplevelsen af den tilstedeværelse, som er så vigtig i en undervisningssituation, eller ved at kompensere for en række teknologiske mangler gennem mere eller mindre kreative remedieringer af tilstedeværelsesundervisningen. Overgangen til et 
synkront onlinemiljø faciliteret af et mangefacetteret værktøj til design af onlinemiljøet (eks AC) åbner også op for nogle helt nye didaktiske muligheder, ligesom teknologien inviterer til en transformation af lærerrollen fra didaktisk designer til også at være læremiddeldesigner. I det følgende vil vi introducere til de vigtigste forskningsresultater fra vores DTU/Ballerup-projekt vedrørende disse innovative transformationer af tilstedeværelsesundervisningen.

a) Asynkron tilgang til liveundervisningen

Dette innovationspotentiale og den transformationsmulighed, der ligger i dette, har været kendt længe, men har indtil videre ikke fået den store udbredelse i Danmark. Afvikles undervisningen i et onlinemiljø som AC, er det nemt for underviseren at optage undervisningen og efterfølgende give de studerende adgang til optagelsen. Vores forundersøgelse i DTU/Ballerup projektet viste, at de studerende meget gerne ville have denne mulighed til repetition mv. Muligheden kendes også fra forsøg med at optage almindelig tilstedeværelsesundervisning, men bl.a. fordi dette er omstændeligt, er denne mulighed ikke slået igennem i større stil i Danmark. I et onlinemiljø er optagelse af undervisningen en hverdagspraksis, som kan sammenlignes med, når underviser distribuerer en PowerPoint el.lign. til de studerende.

b) Læringsmiljøet som læremiddelproduktionsværktøj

Dette innovationspotentiale er en mulighed, som ikke er til stede i tilstedeværelsesundervisningen. Et fuldt udviklet værktøj til design af onlinemiljøer er samtidig et værktøj, der kan anvendes til læremiddelproduktion, hvilket er så stort et potentiale ved teknologien, at vi kunne iagttage, at det var den første didaktiske praksis, som underviserne anvendte værktøjet til i dette projekt. Vi kunne se, at AC både blev anvendt til at designe og facilitere synkron onlinekommunikation, men værktøjet blev også anvendt til, at underviserne producerede sine præsentationer i værktøjet - optog dem på video og distribuerede dem til de studerende. Et værktøj som AC kan derfor fungere både som et værktøj for design af et kommunikationsmiljø, som det rum, hvor onlinekommunikationen foregår, og som værktøj til produktion af asynkrone undervisningsvideoer.

c) Reorganisering af læringsmiljøet "on the fly"

Som mange undervisere har erfaring med fra tilstedeværelsesundervisningen, så er det tidsskrævende at ændre organisering af gruppestørrelser, ressourcer og værktøjer og rum fra et setup til et andet. Vi kunne imidlertid se, at når underviserne i dette projekt skulle restrukturere onlineundervisningen, så kunne de gøre det med blot et enkelt klik. Nogle af underviserne havde nemlig i deres design af 
onlinemiljøet på forhånd, indrettet det med en række submiljøer, og med musen kunne underviserne så blot trække de studerende ud i de grupperum, som var indrettet i forvejen med alle de fem undervisningsmedier vi beskrev ovenfor, ligesom vi kunne se, at submiljøerne var indrettet med en række faglige ressourcer, opgaver mv., som de studerende kunne tage i anvendelse med det samme.

d) Didaktisk designarbejde og læremiddeldesignarbejde integreres

Muligheden for at reorganisere undervisningen "on the fly" styres i ACmiljøet gennem brug af forskellige layouts, som kan indrettes i god tid inden undervisningen. Et layout er rammen om en specifik undervisningssekvens i en onlinesession og jf. ovenfor, så er hvert layout også rammen om den specifikke organisering af læringsmiljøet, man ønsker i denne sekvens - herunder gruppestørrelse og de repræsentationskommunikations- og kollaborationsmedier, man ønsker skal være til stede i denne specifikke organiseringsform. Som designer af undervisningen kan læreren i forvejen overveje dette. Og AC indeholder også en anden mulighed, som må medtænkes, når undervisningen designes med sekvenser og sublæringsmiljøer. De valgte layouts kan nemlig navngives med et navn, der svarer til aktiviteten f.eks. "Velkommen", "Læreroplæg 1 om ...." osv. Hver overskrift genererer et link, der kommer med i den video, som optages af hele undervisningssekvensen, hvilket betyder, at man ved at klikke på undertitlen komme direkte til den sekvens, man ønsker at se, når man genser sessionen. Vi kunne se, at når underviserne i dette projekt anvendte disse muligheder, så stillede det nye krav til undervisernes forberedelse, idet de allerede i deres planlægning både skulle designe et læringsmiljø bestående af flere submiljøer/sekvenser, der understøtter den ønskede undervisning, men samtidig var dette design også et læremiddeldesign for den video, som efterfølgende blev distribueret til de studerende.

\section{e) Didaktiske designs som muliggør didaktiske loops}

Den sidste innovative transformationsdimension, vi har været med til at udvikle i dette projekt er - i modsætning til ovenstående inkrementelle innovationsdimensioner - af den mere radikale slags, og den udfordrer en række gængse forståelser af relationen mellem underviser og den lærerende/de studerende indbyrdes.

Vi har i et tidligere projekt (Christiansen og Gynther 2010) dokumenteret et udbredt problem i formelle læringsmiljøer, at der ikke er transparens i elevers/studerendes læringsaktiviteter. Og underviserens manglende informationer om de studerendes læreprocesbehov betyder, at han/hun har svært ved at give en passende faglig feedback, som kan stilladsere den studerendes arbejde. Dette problem er yderligere blevet forstærket efter, at digitale teknologier har åbnet for de studerendes adgang til alle typer af http://www.lom.dk 
ressourcer og samarbejdsmuligheder, og det er et særligt stort problem i læringsmiljøer, hvor underviser og de studerende ikke til stede i samme fysiske rum - hvilket f.eks. gælder ved gruppeaktiviteter spredt ud over et stort område på campus, eller hvis undervisere og studerende befinder sig $\mathrm{i}$ et onlinemiljø (Christiansen og Gynther 2010).

I et tidligere projekt (op.cit.) formulerede vi den hypotese, at et ideelt didaktisk design, som kunne bidrage til løsningen af ovenstående problem, vil være et didaktisk design, der løbende indsamler information om elever/studerendes aktiviteter med henblik på at etablere passende feedbackmekanismer. Med baggrund i videns- og læringsteori fra kybernetik og systemteori (Bateson, 1988, Luhmann, 2000) formulerede vi den hypotese, at et "ideelt design" er et didaktisk design, hvor undervisningen i tid og aktiviteter er organiseret som et kybernetisk loop. Hermed mener vi, at alle aktiviteter i et undervisningsforløb er feedbackprocesser på de foregående aktiviteter - her konkret, at underviserens aktiviteter skal ses som en konkret feedback på studerendes behov og konkrete læreprocesaktiviteter.

Det er først i DTU/Ballerup-projektet, at vi i en co-designproces mellem forskere og undervisere fik udviklet et helt nyt didaktisk design, som etablerer mulighed for transparens i en række studieprocesser, og som derfor giver underviser mulighed for at iagttage og designe en mulighed for faglig feedback på de studerendes konkrete aktiviteter, ligesom designet også giver mulighed for, at studerende kan iagttage hinandens studieprocesser - en form for lurking som i onlinemiljøer kan have en væsentligt pædagogisk effekt (Gynther 2005).

Prototype for et didaktisk design med didaktiske loops 


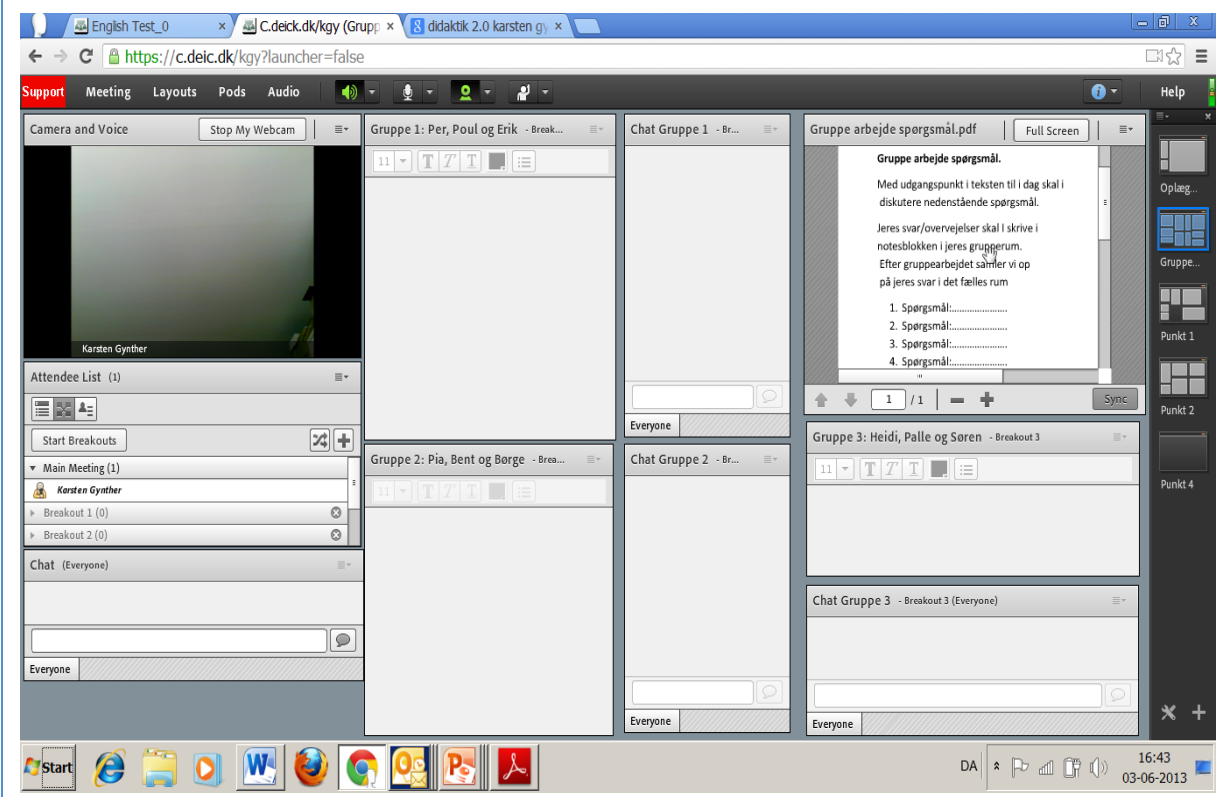

Figur 6. Prototypedesig for didaktiske loop med Adobe Connect

Ovenfor ses et billede af det første designeksempel, der er udviklet med brug af didaktiske loops. Underviser havde indrettet sit onlinemiljø med to forskellige typer af læringsmiljøer: a) Fællesrummet til brug for holdundervisning - fælles opsamlinger mv. og b) Grupperum til brug for studiegruppeaktiviteter i mindre grupper. Hvert grupperum var indrettet med både repræsentationsmedier, dialogmedier, præsentationsmedier og kollaborationsmedier. Det, som er nyt og ikke muligt $\mathrm{i}$ tilstedeværelsesundervisningen, er, at alle kollaborationsmedier i alle grupper samt alle gruppers chatkommunikation replikeres i både fællesrummet (hvor læreren ved grupperumsaktivitetens start befandt sig) samt i alle de andre grupperum. Sidstnævnte funktion gør det muligt at lurke mellem de studerende, en funktion som kan udelades i det didaktiske design enten ved, at underviser undlader at medtage denne designfunktionalitet eller ved, at de studerende selv slår denne mulighed fra.

Det primære i denne prototype er da også, at underviser nu kan iagttage alle gruppers chatkommunikation samt alles gruppers produktion af fælles noter i det kollaborationsmedie, som var til rådighed i grupperummet, og som blev replikeret i fællesrummet. Herved kan underviser iagttage, hvilke grupper, der har størst behov for faglig feedback fra underviseren, hvorefter underviser kan klikke sig ud i grupperummet og give de studerende vejledning over webcam. Muligheden for transparens betyder, at underviser kan differentiere på tid, idet de studerende, som har størst behov for faglig feedback kan få det først, ligesom underviser også kan iagttage, hvis studerende f.eks. ikke har forstået en opgave, hvilket giver 
underviser muligheden for med et klik at "trække" alle studerende tilbage til fællesrummet med henblik på at revidere en instruktion, oplæg el.lign.

De første eksperimenter med denne helt nye prototype for et didaktisk design med loops viser, at det pædagogiske potentiale ifølge udsagn fra underviserne var lovende, men der er nogle praktiske problemer i gennemførelsen, idet det ifølge underviserne er tidskrævende at designe og kræver en del teknisk rutine at afvikle. Og så viste de første eksperimenter og reaktioner fra underviserne, at der - selv om de studerende får at vide, at der er transparens i det didaktiske design - er en række etiske og pædagogiske dilemmaer i dette design vedrørende kontrol og overvågning sat overfor den øgede mulighed for at etablere processer med undervisningsfeedback som direkte og løbende tager udgangspunkt i den studerende forforståelser og læringsbehov.

\section{Perspektivering}

Synkrone online læringsmiljøer er ikke særligt udbredte i Danmark. De lave båndbreder har betydet, at det i forhold til fleksible uddannelser mest har været blended learning-formater med brug af asynkrone kommunikationsformer, som har tegnet billedet. Men asynkrone undervisningsformer kræver stor studiedisciplin og opleves af mange studerende som fjernvær. Her viser dette projekt, at synkrone online læringsmiljøer muliggør udvikling af fleksible uddannelser med tæt lærerfeedback samtidig med, at det faciliterer de studerendes oplevelse af at deltage sammen andre på et fælles hold. Didaktiske principper for design af synkrone læringsmiljøer er imidlertid kun i sin vorden, og her håber vi, at denne artikel kan være et bidrag til udvikling af designframework og didaktiske principper, som kan understøtte undervisere og uddannelsesudviklere i at udvikle denne type læringsmiljøer. 


\section{Referencer}

Alrø, H. \& Dirckinck-Holmfeld, L. (2008). Videoobservation. Aalborg Universitetsforlag.

Amiel, T. \& Reeves, T.(2008). Designbased research and Educational Technology: RethinkingTechnology and the Research Agenda. Educational Technology \& Society, No. 11.

Andreasen, L.B. m.fl. (red.) (2008). Digitale medier og didaktisk design. København: Danmarks Pædagogiske Universitetsforlag.Annand, D. (2011). Social Presence within the Community of Inquiry Framework. International Review of Research in Open \& Distance Learning, 12(5), 4056.

Asterhan, C. \& Scharwz (2009). Online moderation of synchronous eargumentation. Computer-Supported Collaborative Learning. 5: 259-282.

Bateson, G. (1998). De logiske kategorier for læring og kommunikation, Hermansen, M. (red.) Fra læringens horisont. Århus. Klim.

Brown, A. L. (1992). Design experiments: Theoretical and Methodological Challenges in Creating Complex Interventions in Classroom settings. Journal of the Learning Sciences, 2 (22), 141-178.

Christiansen., R \& Gynther, K (2010). Didaktik 2.0 - didaktisk design for skolen i vidensamfundet. In: Gynther, Karsten (red.): Didaktik 2.0. København. Akademisk forlag.

Christensen 0., Gynther, K. og Petersen, T. (2012). Design Based Research introduktion til en forskningsmetode i udvikling af nye elæringskoncepter medieret af digitale teknologier. Læring og Medier (LOM) - nr. 9 - 2012

Collins, A. (1992). Towards a design science of education, E. Scanlon \& T. 0'Shea (Eds.), New Directions in Educational Technology (pp. 15-22). Berlin: Springer.

Deleuze, Gilles (1999). Foucault, London: Continuum

Dirckinck-Holmfeld, L. (2004). Et europæisk perspektiv på e-læring. In: Knastrup, Anne Marie (red.): E-læring på arbejde. Roskilde Universitetsforlag.

diSessa, A. A., \& Cobb, P. (2004). Ontological Innovation and the Role of Theory in Design Experiments. Journal of The Learning Sciences, 13(1), 77-103.

Dohn, N. B. og Johnsen, L. (2009). E-læring på web 2.0. København. Samfundslitteratur.

Edelson, D. C. (2006). What we learn when we engaged in design: Implication for assessing 
Design Research, J. V. D. Akker, K. Gravemeijer, S. McKenney \& N. Nieveen (Eds.),

Educational Design Research, London \& New York: Routledge.

Ejersbo, L. R. m.fl. (2008). Balancing Product Design and Theoretical Insights, Kelly,

Anthony mfl. (ed.). Handbook of Design Research Methods in Education. Routledge.

Frederiksen J., Christensen 0., Gynther, K. og Petersen, T. (2013). Kvalitativ og kvantitativ kortlægning af potentialer og barrierer for udvikling af blended learning uddannelser på Ingeniørhøjskolen i København. Sorø. UCSJ forlag.

Garison, D. R. and Vaughan, N. D. (2008). Blended learning in higher education. San Francisco. Jossey-Bass.

Garison, D. R. (2011 opr. 2003). E-learning in the 21st century. New York. Routledge.

Gibson, J. J. (1977). The theory of affordances, R. E. Shaw \& J. Bransford (Eds.), Perceiving, Acting, and Knowing. Hillsdale, NJ: Lawrence Erlbaum Associates.

Gibson, J.J. (1986). The Ecological Approach to Visual Perception, Hillsdale, NJ: Lawrence Earlbaum Associates, Inc.

Glaser, B. G. \& Strauss, A.L. (1967/ 2008): The Discovery of Grounded Theory: Strategies for Qualitative Research. New Brunswick, New Jersey: Aldine Transaction.

Gorsky, P. and Caspi, A. (2005). A critical analysis of transactional distance theory. The Quarterly Review of Distance Education, Vol. 6(1), 1-11.

Gravemeijer, S. McKenney \& Nieveen, N. (Eds.). Educational Design Research. London \& New York: Routledge.

Gynther, Karsten (2005). Blended Learning. København. Unge pædagoger.

Gynther, Karsten (red.) (2010). Didaktik 2.0. København. Akademisk forlag.

Hastie, Megan mfl. (2007). Instructional Design for Best Practice in the Synchronous Cyber Classroom. Educational Technology \& Society, 10(4), 281-294.

Hrastinski, S. m.fl. (2010). Design exemplars for synchronous e-learning: A design theory approach. Computers \& Education. 55: 652-662.

Hwaang, Wu-Yuin mfl. (2012). Effects of Speech-to-Text Recognition Application on Learning Performance in Synchronous Cyber Classrooms. Educational Technology \& Society. 15(1), 367-380. 
Illeris, K. (1981). Modkvalificeringens pædagogik - problemorientering, deltagerstyring og eksemplarisk læring. København, Unge PædagogerJenkins, H.S. (2008). Gibson's "Affordances": Evolution of a pivotal concept, Journal of Scientific Psychology, 34-45, Dec. 2008.

Karal, H. mfl. (2011). Perceptions of students who take synchronous courses through video conferencing about distance education. The Turkish Online Journal of Educationl Technology. Vol. 10, Issue 4.

Kilbourn, K., and Isaksson, J. (2007). Meaning through doing: the role of affordances over time Working paper and presentation of the 6th Nordcode Seminarand workshop, Helsinki, Finland.

Lee, K. M. (2004). Presence, explicated. Communication Theory, 14(1), 2750.

Li, K. m.fl. (2011). On Synchronous Distance Teaching in a Mathematics MS Program. US- China Education Review. A 6, 761-767.

Luhmann, N. (2000). Sociale systemer. København. Hans Reitzel.

McBrien, J. L. m.fl. (2009). Virtual Spaces: Employing a Synchronous Online Classroom to Facilitate Student Engagement in Online Learning. International Review of Research in Open and Distance Learning. Vol. 10 nr. 3.

McGrenere, J., and Ho, W. (2000). Affordances: Clarifying and evolving a concept. Proceedings of Graphics Interface 2000, 179-186.

McKenney, S., Nieveen, N., \& Akker, J. v. d. (2006). Design Research from a Curriculum perspective, Akker, J. V. D.m.fl. (Eds.), Educational Design Research. London \& New York: Routledge.

Minsky, M. (1980). Telepresence. Omni magazine (June), 44-52.

Moore, M. G. (1993): Theory of transactional distance, D. Keegan, (Ed.): Theoretical principles of distance education. New York. Routledge.

Nehme, Z. m.fl. (2008). The social arena of the online synchronous environment. Turkish Online Journal of Distance Education. Vol. 9, nr. 2. Article 14.

Nieveen, N., McKenney, S., \& Akker, J.v. d. (2006). Educational Design Research: The value of variety, Akker, J. V. D.m.fl. (Eds.), Educational Design Research. London \& New York: Routledge.

Norman, Donald (1988). The design of everyday things. London. MIT press.

Pawson, R. og Tilley, N. (1997). Realistic Evaluation. London. Sage.

Qvortrup, L. (2001): Det lærende samfund. København. Gyldendal.

Ravn, Ib (2010). Transformative forskningsmetode - belyst gennem et projekt om mødefacilitering. Tidsskrift for arbejdsliv, 12 årg. nr. 1. 
Reeves, T. (2006). Design Research from a Technology perspective. In J. V. D. Akker m.fl (ed.).Educational Design Research. London \& New York: Routledge

Rich, L.L. m.fl. (2009). Collaborate, Engage and Interact in Online Learning: Successes with Wiki and Synchronous Virtual Classrooms at Athens State University. Paper presented at the $14^{\text {th }}$ Annual Instructional Technology Conference.

Robertson, L. and Hardman, W. (2012). Entering new territory: Crossing over to fully synchronous e-learning courses. College Quarterly, Vol. 15, nr. 3.

Stoffregen, T. (2000). Affordances and events. Ecological Psychology, 12, 128.

Strayer, F. J. (2007). The effects of the classroom flip on the learning environment: A comparison of learning activity in a traditional classroom and a flip classroom that used an intelligent tutoring system. The Ohio State University.

Sullivan, F. R. m.fl. (2010). Representational guidance and student engagement: examining designs for collaboration in online synchronous environments. Education Tech Research, 59:619-644.

Sung, E. \& Mayer, R. E. (2012). Five facets of social presence in online distance education. Computers in Human Behavior, 28(5), 1738-1747.

Teng, D. M.fl. (2012): Exploring students learning experience in an international online research seminar in the Synchronous Cyber Classroom. Computers \& Education, 58: 918-930.

The design-based Research Collective. (2003). Design- Based Research: An Emergingparadigm for Educational Inquiry. Educational Researcher, 32(1), 5-8.

Tucker, B. (2012). The flipped Classroom. Online instruction at home frees class time for learning, Education Next Winter 2012/ Vol. 12, No 1.

Wang, M-J (2010). Online collaboration and offline interaction between students using asynchronous tools in blended learning. Australasian Journal of Educational Technology, 26(6), 830-846.

Whitworth, Brian (2009): The Social Requirements of Technical Systems, Whitworth, B., and Moor, A.d. (eds.), Handbook of Research on SocioTechnical Design and Social Networking Systems. IGI, Hershey, PA. 